SHORT REPORT

\title{
Administering a glyceryl trinitrate infusion: big is not always best
}

\section{Matthew J Reed}

Emerg Med J 2007;24:423-424. doi: 10.1136/emj.2006.042119

With the use of some simple calculations it can be demonstrated that the choice of cannula and initial glyceryl trinitrate (GTN) infusion rate for patients with acute left ventricular failure (LVF) requires some careful thought. If a GTN infusion is commenced at a rate of $1 \mathrm{ml} / \mathrm{h}$, a critically unwell patient with a large cannula-for example, a grey cannula-will have to wait over $6 \mathrm{~min}$ for the drug to enter the body. This compares with $1.5 \mathrm{~min}$ for a pink cannula at the same infusion rate. If a largediameter cannula is chosen for these patients, then a fast initial infusion rate should also be chosen to ensure that the GTN begins to act quickly. The rate can later be adjusted depending on clinical conditions.

A n infusion of glyceryl trinitrate (GTN) is one of the key components in the treatment of acute left ventricular failure (LVF). Patients can be extremely unwell and are therefore often managed in the emergency department resuscitation room, a place where it is not unusual for larger intravenous cannulae to be sited. The following calculation shows that the adage "big is best" is not always the case.

\section{METHODS}

GTN or nitrocine is available at a concentration of $1 \mathrm{mg} / \mathrm{ml}$, and in the treatment of acute LVF is often administered undiluted via a syringe pump at a rate of $10-200 \mu \mathrm{g} / \mathrm{min} .{ }^{1}$ This is equivalent to $0.01-0.2 \mathrm{ml} / \mathrm{min}$ or $0.6-12.0 \mathrm{ml} / \mathrm{h}$. This is the origin of the often quoted initial rate of infusion of $0.6 \mathrm{ml} / \mathrm{h}$. Before starting an infusion, the GTN solution is flushed through to the end of the giving set and then connected to the intravenous cannula. The time taken for the infusion to pass through the cannula, enter the patient's vein and start its effect depends on the volume of dead space inside the cannula and the chosen initial infusion rate.

Table 1 details the characteristics of five commonly used intravenous cannulae. ${ }^{2}$ The volume of each cannula was calculated (length multiplied by radius squared multiplied by П) in $\mathrm{mm}^{3}$. This was then converted to millilitres ( $1 \mathrm{ml}=1 \mathrm{~cm}^{3}=1000 \mathrm{~mm}^{3}$, therefore $1 \mathrm{~mm}^{3}=0.001 \mathrm{ml}$ ). The rate of infusion in millilitres per hour was divided by 3600 to convert it to millilitres per second. The time in seconds for the
Table 1 Characteristics of five commonly used intravenous cannulae

\begin{tabular}{llllc}
\hline Cannula & Gauge & $\begin{array}{l}\text { Diameter } \\
(\mathbf{m m})\end{array}$ & $\begin{array}{l}\text { Length } \\
(\mathbf{m m})\end{array}$ & $\begin{array}{l}\text { Volume of } \\
\text { cannula } \\
\left(\mathbf{m m}^{3}\right)\end{array}$ \\
\hline Blue & 22 & 0.8 & 25 & 12.6 \\
Pink & 20 & 1.0 & 32 & 25.1 \\
Green & 18 & 1.2 & 45 & 50.9 \\
Grey & 16 & 1.7 & 45 & 102.1 \\
Orange & 14 & 2.0 & 45 & 141.3 \\
\hline
\end{tabular}

infusion to pass through the dead space inside the cannula was then calculated (volume of cannula in millilitres divided by infusion rate in millilitres per second; table 2) for each of the five GTN infusion rates.

\section{RESULTS}

If a GTN infusion is started at $1 \mathrm{ml} / \mathrm{h}$, a critically unwell patient with a large cannula-for example, a grey cannula-will have to wait over 6 min for the drug to enter the body, compared with $1.5 \mathrm{~min}$ for a pink cannula at the same infusion rate. Increasing the infusion rate to $5 \mathrm{ml} / \mathrm{h}$, for example, reduces the dead space time to $74 \mathrm{~s}$ for a grey cannula and $18 \mathrm{~s}$ for a pink cannula. The larger the cannula chosen and the slower the infusion rate selected, the longer the cannula lead time before the drug becomes active.

I acknowledge that these observations are only theoretical. Once the time taken to set up a GTN infusion and start other treatments, such as non-invasive ventilation, is taken into account, it is difficult to know how much the choice of cannula size actually contributes to patient outcome. As a recommendation for everyday practice, however, choice of cannula size and initial infusion rate may be worth more thought.

\section{CONCLUSION}

In critically unwell patients with acute LVF, if a bigger cannula is chosen then a high initial infusion rate should also be chosen

Abbreviations: GTN, glyceryl trinitrate; LVF, left ventricular failure

Table 2 Time in minutes and seconds for the glyceryl trinitrate infusion to pass through the dead space inside the cannula at different rates of infusion $(0.6,1.0,2.0,5.0$ and $12.0 \mathrm{ml} / \mathrm{h})$

\begin{tabular}{lrrrrr}
\hline Cannula & 0.6 & 1.0 & 2.0 & 5.0 & 12.0 \\
\hline Blue & $1 \mathrm{~min}, 15 \mathrm{~s}$ & $0 \mathrm{~min}, 45 \mathrm{~s}$ & $23 \mathrm{~s}$ & $9 \mathrm{~s}$ & $4 \mathrm{~s}$ \\
Pink & $2 \mathrm{~min}, 31 \mathrm{~s}$ & $1 \mathrm{~min}, 30 \mathrm{~s}$ & $45 \mathrm{~s}$ & $18 \mathrm{~s}$ & $8 \mathrm{~s}$ \\
Green & $5 \mathrm{~min}, 5 \mathrm{~s}$ & $3 \mathrm{~min}, 3 \mathrm{~s}$ & $1 \mathrm{~min}, 32 \mathrm{~s}$ & $37 \mathrm{~s}$ & $15 \mathrm{~s}$ \\
Grey & $10 \mathrm{~min}, 13 \mathrm{~s}$ & $6 \mathrm{~min}, 8 \mathrm{~s}$ & $3 \mathrm{~min}, 4 \mathrm{~s}$ & $1 \mathrm{~min}, 14 \mathrm{~s}$ & $31 \mathrm{~s}$ \\
Orange & $14 \mathrm{~min}, 8 \mathrm{~s}$ & $8 \mathrm{~min}, 29 \mathrm{~s}$ & $4 \mathrm{~min}, 14 \mathrm{~s}$ & $1 \mathrm{~min}, 42 \mathrm{~s}$ & $42 \mathrm{~s}$ \\
\hline
\end{tabular}


to ensure that the GTN begins to act quickly. Once the drug has passed through the cannula, the rate of administration should be adjusted depending on the clinical condition of the patient and blood pressure constraints.

Competing interests: None.

Correspondence to: Dr M J Reed, Department of Emergency Medicine, Royal Infirmary of Edinburgh, 51 Little France Crescent, Edinburgh EH16 4SA, UK; mattreed1@hotmail.com
Accepted 21 February 2007

\section{REFERENCES}

1 Joint Formulary Committee. British National Formulary, 51 st edn. London: British Medical Association and Royal Pharmaceutical Society of Great Britain, 2006, 105-106.

2 Ohmeda Medical. Venflon product information. Uppsala, Sweden: Ohmeda Medical, Healthcare Bio-Sciences AB.

\section{BMJ Clinical Evidence-Call for contributors}

BMJ Clinical Evidence is a continuously updated evidence-based journal available worldwide on the internet which publishes commissioned systematic reviews. BMJ Clinical Evidence needs to recruit new contributors. Contributors are healthcare professionals or epidemiologists with experience in evidence-based medicine, with the ability to write in a concise and structured way and relevant clinical expertise.

Areas for which we are currently seeking contributors:

- Secondary prevention of ischaemic cardiac events

- Acute myocardial infarction

- MRSA (treatment)

- Bacterial conjunctivitis

However, we are always looking for contributors, so do not let this list discourage you.

Being a contributor involves:

- Selecting from a validated, screened search (performed by in-house Information Specialists) valid studies for inclusion.

- Documenting your decisions about which studies to include on an inclusion and exclusion form, which we will publish.

- Writing the text to a highly structured template (about 1500-3000 words), using evidence from the final studies chosen, within 8-10 weeks of receiving the literature search.

- Working with BMJ Clinical Evidence editors to ensure that the final text meets quality and style standards.

- Updating the text every 12 months using any new, sound evidence that becomes available. The BMJ Clinical Evidence in-house team will conduct the searches for contributors; your task is to filter out high quality studies and incorporate them into the existing text.

- To expand the review to include a new question about once every 12 months.

In return, contributors will see their work published in a highly-rewarded peer-reviewed international medical journal. They also receive a small honorarium for their efforts.

If you would like to become a contributor for BMJ Clinical Evidence or require more information about what this involves please send your contact details and a copy of your CV, clearly stating the clinical area you are interested in, to CECommissioning@bmigroup.com.

\section{Call for peer reviewers}

BMJ Clinical Evidence also needs to recruit new peer reviewers specifically with an interest in the clinical areas stated above, and also others related to general practice. Peer reviewers are healthcare professionals or epidemiologists with experience in evidence-based medicine. As a peer reviewer you would be asked for your views on the clinical relevance, validity and accessibility of specific reviews within the journal, and their usefulness to the intended audience (international generalists and healthcare professionals, possibly with limited statistical knowledge). Reviews are usually 1500-3000 words in length and we would ask you to review between 2-5 systematic reviews per year. The peer review process takes place throughout the year, and our turnaround time for each review is 10-14 days. In return peer reviewers receive free access to BMJ Clinical Evidence for 3 months for each review.

If you are interested in becoming a peer reviewer for BMJ Clinical Evidence, please complete the peer review questionnaire at www.clinicalevidence.com/ceweb/contribute/peerreviewer.jsp 